\title{
THE INFLUENCE OF ORAL HYGIENE EDUCATION ON THE ORAL HEALTH STATUS OF PATIENTS SUFFERING FROM HIV/AIDS
}

\author{
Yohanis Lefta ${ }^{1}$, Rosyidah Arafat ${ }^{2}$, Syahrul Syahrul ${ }^{3}$. \\ 1. Poltekkes Kemenkes Maluku \\ 2,3 Faculty of Nursing, Universitas Hasanuddin \\ e-mail:leftamihel@gmail.com
}

\begin{abstract}
Introduction: Poor oral hygiene and dental care can affect oral intake which results in decreased endurance and increases the risk of opportunistic or systemic infections. Method: The research was carried out the RSUD dr. M. Haulussy Ambon, Maluku, Indonesia, using a quasi-experimental method, involving 30 nurses and 20 patients. The level of knowledge and skills is evaluated before and after oral hygiene education for nurses. Patients were measured with a Beck Oral Assessment Scale (BOAS) score, and C. albicans yeast culture before and after the intervention was given in the form of oral hygiene using a soft toothbrush and dental floss for one week. Result: The influence of oral hygiene education on nurses knowledge with median value of pre-education 36.00 and posteducation 91.00 and nurse skills have median value of pre-education 67.00 and posteducation 100.00 with a significant value of $\mathrm{p}=0.001<0.05$. There is an increase in knowledge and skills after educational activities. Before oral hygiene treatment was applied with a review of the BOAS score it had a median value of 11.00 after the intervention became 6.00 a significant value of $p=0.001<0.05$, which showed a decrease in scores after oral hygiene treatment. Examination of C. albicans fungus with a median value of 79.00 pre-intervention and 31.00 at post-intervention, a significant value of $\mathrm{p}=0.001$, showed a decrease in the number of post-intervention fungi. Conclusion: Nurses should conducted Oral hygiene regularly to improve oral health status of AIDs patiens.
\end{abstract}

Keywords: Education, Nurses' Oral Hygiene, Patients with AIDS.

\section{PENDAHULUAN}

Pasien dengan HIV/AIDS mempunyai sistem kekebalan tubuh yang terganggu sehingga pasien akan mengalami banyak keluhan. Salah satu keluhan yang ditemui pada pasien dengan HIV/AIDS adalah lesi pada mulut. Awal tahun 1990-an, studi ilmiah memperkirakan bahwa pasien HIV/AIDS sebanyak 90\% dapat mempunyai setidaknya satu gejala penyakit mulut selama periode penyakit yang mereka alami (Fox et al., 2012).

Di negara barat dilaporkan prevalensi lesi oral pada HIV/AIDS adalah 56\%. Salah satu lesi oral yang berhubungang dengan HIV adalah kandidiasis oral (Kuteyi \& Okwundu, 2012) dan merupakan manifestasi oral yang umum pada pasien dengan
HIV/AIDS (Mwangosi \& Majenge, 2011). Kandidiasis pada pasien terinfeksi HIV lebih dari $60 \%$ dan terjadi lebih dari $80 \%$ pada kasus AIDS (Krishnan, 2012). Kandidiasis menyebabkan gangguan pada sistem pencernaan diantaranya penurunan berat badan yang cepat dan progresif, intoleransi terhadap intake, kesulitan mengunyah dan menelan (Doengoes, Moorhouse, \& Murr, 2015).

Mulut sebagai pintu gerbang masuk ke tubuh dan mulut dapat memberikan sinyal defisiensi nutrisi dan berfungsi sebagai sistem peringatan awal untuk berbagai penyakit terutama yang berhubungan dengan sistem kekebalan tubuh seperti HIV/AIDS (Fox et al., 2012). Karena jika terjadi defisiensi nutrisi berakibat pada kekurangan protein 
yang mana merupakan penunjang untuk pembentukan kekebalan tubuh pasien (Doengoes, et al., 2015).

Kebersihan mulut (Oral hygiene) dan perawatan gigi yang buruk dapat mempengaruhi asupan oral dan meningkatkan risiko infeksi oportunistik dan sistemik. Asupan oral yang buruk dapat berakibat defisit nutrisi yang selanjutnya dapat merusak sistem kekebalan tubuh. Mukosa mulut dapat dengan cepat menunjukkan komplikasi yang parah dan progresif; Oleh karena itu, langkah-langkah pencegahan dan intervensi awal sangat penting et al., 2015). Perawatan mulut (Oral hygiene) merupakan bagian penting dari perawatan untuk semua pasien, kelompok yang memiliki kebutuhan spesifik sering menjalani perawatan yang lebih ditujukan pada perawatan mulut (Salamone, Yacoub, Mahoney, \& Edward, 2013).

Perawatan kesehatan mulut adalah peran kunci yang harus dilakukan oleh perawat dalam mengidentifikasi tanda-tanda untuk penilaian pasien yang beresiko terhadap mucositis, penyakit periodontal (inflamasi kronis), infeksi kronis, termasuk kandidiasis serta menilai kemandirian pasien dalam perawatan mulut (Salamone et al., 2013). Tim profesional perawat berperan menerapkan protokol kebersihan mulut dalam suatu studi tentang oral hygiene yang membandingkan penerapan klorheksidin dan menyikat gigi (kebersihan mekanis) untuk mencegah pneumonia akibat ventilator (Fernanda et al., 2017). Oleh karena itu perawat harus memiliki pengetahuan yang memadai tentang perawatan mulut terutama terhadap pasien HIV/AIDS.

$\begin{array}{rrr}\text { Namun perawat mengalami } \\ \text { hambatan } & \text { ketika }\end{array}$ menerapkan oral hygiene sehari-hari secara rutin. Hambatan tersebut berupa pendidikan dan pelatihan staf yang buruk khususnya dalam pelaksanaan oral hygiene pada kondisi fisik yang sulit, tidak adanya prosedur kebersihan mulut yang formal, peralatan dan prioritas penyelesaian pekerjaan yang bersaing (Gibney, Wright, Sharma, \& Naganathan, 2015).

Temuan dari sebuah studi menunjukkan bahwa pendidikan perawatan mulut yang substansial tidak dimiliki oleh perawat, baik pada pendidikan awal maupun dalam proses kualifikasi sebagai perawat. Pengetahuan tentang kesehatan mulut dasar yang dimiliki oleh reponden tidak memadai demikian juga pengetahuan tentang peralatan kesehatan mulut dan efek samping dari penggunaan obat-obat perawatan mulut (Groenkjaer, 2015).

Perawat memiliki sedikit pemahaman tentang seberapa umum praktik klinis menyediakan perawatan kebersihan mulut dan ada kebutuhan agar memasukan layanan ini dalam penyediaan perawatan secara keseluruhan (Fjeld et al. 2017; Malik, 2017). Berbeda dengan ini, data dari sebuah studi tentang manfaat biaya dan layanan HIV nasional menemukan bahwa, sejak mengetahui status HIV-positif mereka, hanya 26\% ODHA yang melaporkan flushing setiap hari, 34\% melaporkan lebih sering menyikat dan flushing, $23 \%$ melaporkan mengunjungi dokter gigi dengan frekuensi lebih sedikit, dan $11 \%$ melaporkan tidak pernah melakukan pemeriksaan diri (Rajabiun et al., 2012).

Berdasarkan hasil wawancara dan pengamatan yang dilakukan di ruangan perawatan RSUD Dr. M. Haulussy Ambon, didapatkan bahwa dalam pelaksanaan perawatan pasien HIV/AIDS dengan kandidiasis; tidak dilakukan oral hygiene, penanganan hanya dengan agen farmakologik, namun sesuai standar diagnosa keperawatan Indonesia (SDKI), dimana salah satu intervensi pada pasien dengan HIV adalah melakukan 
oral hygiene (Nursalam, Ninuk, Misutarno, \& Kurniasari, 2018). Maka dipandang perlu adanya pendidikan kesehatan oral untuk meningkatkan kesadaran dan pemahaman juga sebagai penyegaran pengetahuan perawat dalam hal perawatan mulut pasien HIV/AIDS.

Namun pendidikan dan pengetahuan yang berhubungan dengan kesehatan mulut pada perawat yang bekerja dalam perawatan pasien dengan HIV/AIDS telah menarik perhatian dan sangat sedikit yang diketahui tentang pengelolaan kesehatan mulut bagi pasien mereka, sehingga ada kebutuhan untuk meneliti tentang pendidikan dan pengetahuan perawat dalam menilai dan menerapkan perawatan mulut untuk pasien dengan HIV/AIDS.Tujuan dari penelitian ini adalah untuk mengetahui pengaruh dari edukasi Oral Hygiene pada perawat terhadap status kesehatan mulut pasien dengan HIV/AIDS.

\section{METODE}

Penelitian ini merupakan penelitian kuantitatif dengan desain kuasi eksperimen atau eksperimen semu yang tidak memiliki ciri pengacakan (random) untuk kondisi perawatan. Desain penelitian ini menerapkan perlakuan pada kelompok perawat dengan diobservasi sebelum dan sesudah intervensi dan mengevaluasi sebelum dan sesuah hasil penerapan oral hygiene dari perawat kepada pasien HIV/AIDS. Pelaksanaan penelitian dibagi dalam dua tahap, pertama adalah kegiatan edukasi tentang oral hygiene bagi perawat yang bertugas di ruang rawat inap penyakit dalam dan tahap kedua berupa penerapan oral hygiene kepada pasien penderita HIV/AIDS yang menjalani perawatan di Rumah Sakit Umum Daerah Dr. M. Haulussy Ambon. Penelitian ini telah memeproleh izin etik dari komisi etik Institusi asal.
Metode sampling yang
digunakan adalah Propability

Sampling dilakukan secara acak sederhana (simple random sampling) dengan melakukan undian, kemudian diambil 31 sampel untuk intervensi yang telah disesuaikan dengan kriteria inklusi.

Pemilihan perawat yang dimasukan dalam penelitian ini menggunakan kriteria inklusi; perawat yang bertugas di ruang interna, yang mengikuti kegiatan edukasi oral hygiene, sedangkan perawat yang dikeluarkan (ekslkusi) dari penelitian adalah perawat yang tidak mengikuti kegiatan edukasi dan tidak menyelesaikan kuesioner pre dan post edukasi. Sedangkan pasien yang sesuai kriteria inklusi, yakni diagnosa zeropositive HIV, menyetujui Informconsent, menerima terapi antiretroviral serta kriteria eksklusinya adalah pasien yang sedang menjalani perawatan ortodontik, menderita penyakit lain yang mempengaruhi aliran saliva, pasien dengan kepatuhan terbatas.

Instrumen yang digunakan dalam penelitian ini adalah Kuesioner pengetahuan mengenai oral hygiene, Lembar observasi ketrampilan perawat, Kuesioner Beck Oral Assessment Scale (BOAS) dan hasil pemeriksaan laboratorium terhadap jumlah C. albicans.

Setelah memeperoleh izin etik dari komisi etik, kemudian peneliti mengajukan permohonan izin ke pihak rumah sakit dan mempersiapkan instrumen penelitian serta mengidentifikasi responden. Kemudian peneliti melakukan sosialisasi maksud dan tujuan penelitian kepada responden yang telah dipilih sesuai kriteria inklusi dan eksklusi, selanjutnya memberikan Informconsent dan melakukan kontrak waktu dengan responden untuk penelitian selama satu minggu. Hari pertama diawali dengan pengukuran tingkat pengetahuan dan ketrampilan 
perawat pre edukasi, dilanjutkan dengan pendidikan kesehatan oral hygiene kepada parawat, kemudian pengukuran tingkat pengetahuan dan ketrampilan post edukasi.

Tahap berikutnya adalah penilaian status kesehatan mulut pasien pre intervensi dengan menggunakan skor Beck Oral Assessment Scale (BOAS) dengan skor: 0-5 merupakan kondisi normal, 6-10 disfungsi ringan, 11-15 disfungsi sedang, 16-20 disfungsi berat (Ames, et al., 2011) dan pengambilan sampel untuk pemeriksaan C. albicans, kemudian perawat menerapkan intervensi oral hygiene kepada pasien dengan menggunakan sikat gigi berbulu lembut dan pasta gigi serta peggunaan dental floss selama tujuh hari. Prosedur perawatan mulut tersedia dalam Konsep Dasar Keperawatan (Potter, Perry, Stockert, \& Hall, 2013), perawat bertugas mengatur posisi pasien, menyiapkan peralatan oral hygiene, kemudian meminta pasien untuk melakukan sendiri bagi pasien yang dapat melakukannya sambil perawat mengajari dan mengawasi karena kondisi kandidiasis yang dialami oleh pasien, setelah itu posisi pasien diatur kembali dan peralatan dirapikan. Selanjutnya dilakukan pengukuran skala BOAS dan pengambilan sampel swab untuk pemeriksaan laboratorium post intervensi.

Responden yang terlibat dalam penelitian ini pada awalnya adalah sebanyak 37 orang perawat, namun enam responden tidak dapat mengikuti evaluasi akhir dan pengisian kuesioner post edukasi sehingga sisa 31 responden perawat. Sebanyak 23 pasien yang didiagnosis HIV/AIDS, namun tiga responden tidak dapat menyelesaikan proses oral hygiene karena diperbolehkan pulang setelah kondisinya mulai membaik sebelum dilakukan evaluasi.

Hipotesis dalam penelitian ini adalah: Edukasi oral hygiene dapat meningkatkan pengetahuan perawat tentang oral hygiene pada penderita HIV/AIDS dan penerapan oral hygiene dapat meningkatkan status kesehatan mulut penderita HIV/AIDS.

Pengumpulan data dilakukan setelah responden menandatangani informed consent meliputi data demografi responden (perawat dan pasien) yang diperoleh dari lembar kuesioner yang diberikan dan dilengkapi dengan data dari catatan rekam medik pasien. Pengolahan data dilakukan setelah semua data yang diperlukan sudah terkumpul dan telah dilengkapi termasuk hasil pemeriksaan laboratorium. Pengolahan dan analisis data menggunakan analisis univariat dan analisis bivariat dengan program SPSS dan uji Wilcoxon digunakan untuk menilai hasil pre dan post intervensi yang memiliki sebaran data tidak normal.

HASIL

Penelitian dilakukan pada tanggal 19 Agustus s.d. 19 September 2019 di Rumah Sakit Dr. M. Haulussy Ambon dengan izin etik dari komisi etik Fakultas Kedokteran Universitas Hasanuddin.

Data karakteristik demografi 31 responden perawat pada penelitian ini menunjukkan bahwa rata-rata perawat berusia $37(36,68)$ tahun dengan jenis kelamin perempuan $(83.9 \%)$ lebih banyak dari laki-laki (16.1\%), sebagian besar berlatarbelakang pendidikan D3 Keperawatan (71\%), sedangkan sisanya $(29 \%)$ berlatarbelakang penddikan $\mathrm{S} 1+$ Ners dan rata-rata masa kerja $11 \quad(11,39$ tahun, ditampilkan pada tabel 1 . 


\begin{tabular}{lc}
\hline Karakteristik Responden & $\begin{array}{c}\text { Jumlah (n= 31) } \\
\mathrm{n}(\%)\end{array}$ \\
\hline $\begin{array}{l}\text { Umur } \\
\text { (Mean } \pm \mathrm{SD})\end{array}$ & $(36.68 \pm 6.305)$ \\
Jenis Kelamin & $5(16.1)$ \\
$\quad$ Laki-laki & $26(83.9)$ \\
$\quad$ Perempuan & \\
Pendidikan & $22(71,0)$ \\
$\quad$ D3 & $9(29,0)$ \\
S1+Ners & \\
Lama Kerja & $(11.39 \pm 5.649)$ \\
$\quad$ (Mean \pm SD)
\end{tabular}

Tabel 1. karakteristik demografi responden perawat

\begin{tabular}{lc}
\hline Karakteristik Responden & $\begin{array}{c}\text { Responden (n= 20) } \\
\mathbf{n}(\%)\end{array}$ \\
\hline Umur (Tahun) & \\
(Mean + SD) & $(33.85 \pm 9.360)$ \\
Jenis Kelamin & $13(65)$ \\
$\quad$ Laki-laki & $7(35)$ \\
Perempuan & $2(10)$ \\
Pendidikan & $15(75)$ \\
$\quad$ SMP & $3(15)$ \\
SMA & $7(35)$ \\
PT & $1(5)$ \\
Status Perkawinan & $12(60)$ \\
Belum Menikah & $7(35)$ \\
Janda / Duda & $1(5)$ \\
Menikah & $10(50)$ \\
Pekerjaan & $2(10)$ \\
Tidak/Belum Bekerja & \\
Buruh/Karyawan & $(5.20 \pm 2.367)$ \\
Swasta/LSM & \\
PNS/TNI/POLRI & \\
Lama Terinfeksi (Tahun) & \\
(Mean \pm SD) & \\
\hline
\end{tabular}

Tabe1 2. karakteristis demografi responden pasien.

\begin{tabular}{llllll}
\hline Pengetahuan perawat & \multicolumn{2}{l}{ Mean (SD) } & \multicolumn{2}{c}{ Median (Min - Max) } & Nilai $\boldsymbol{p}$ \\
\hline Pre edukasi & 40.48 & $(25.58)$ & 36.00 & $(9-82)$ & \\
Post edukasi & 93.90 & $(5.87)$ & 91.00 & $(82-100)$ & 0.001
\end{tabular}

Tabel 3. Pengaruh Edukasi Oral hygiene terhadap pengetahuan perawat.

\begin{tabular}{lccc}
\hline $\begin{array}{c}\text { Ketrampilan } \\
\text { perawat }\end{array}$ & Mean (SD) & $\begin{array}{c}\text { Median } \\
\text { (Min - Max) }\end{array}$ & Nilai $\boldsymbol{p}$ \\
\hline Pre edukasi & $66.26(10.55)$ & $67.00(50-83)$ & 0.001 \\
Post edukasi & $98.58(1.95)$ & $100.00(96-100)$ & \\
\hline
\end{tabular}

Tabel 4. Pengaruh Edukasi Oral hygiene terhadap keterampilan perawat 


\begin{tabular}{|c|c|c|c|}
\hline Skor BOAS & Mean (SD) & Median (Min - Max) & Nilai $p$ \\
\hline Pre intervensi & $11.10(2.15)$ & $11.00(8-15)$ & \multirow{2}{*}{$0.001^{*}$} \\
\hline Post intervensi & $6.20(1.20)$ & $6.00 \quad(5-9)$ & \\
\hline
\end{tabular}

Tabel 5. Pengaruh penerapan Oral hygiene Terhadap Skor BOAS sebelum dan sesudah Intervensi

\begin{tabular}{lccc}
\hline \multicolumn{1}{c}{ C. Albicans } & Mean (SD) & $\begin{array}{c}\text { Median } \\
\text { (Min-Max) }\end{array}$ & Nilai P \\
\hline $\begin{array}{l}\text { Jumlah C. albicans Pre } \\
\text { Intervensi }\end{array}$ & $112.90(89.05)$ & $79.00(22-400)$ & 0,001" \\
$\begin{array}{l}\text { Jumlah C. albicans Post } \\
\text { Intervensi }\end{array}$ & $52.75(45.92)$ & $31.00(10-167)$ & \\
\hline
\end{tabular}

Tabel 6. Pengaruh pre dan post penerapan oral hygiene terhadap jumlah Candida albicans oral.

Karakteristik demografi pasien sebanyak 20 responden rata-rata berusia $34(33,85)$ tahun dengan jenis kelamin laki-laki (65\%) lebih banyak dari perempuan $(35 \%)$, sebagian besar berlatarbelakang pendidikan SLTA $(75 \%)$ dengan status perkawinan sebanyak (60\%) menikah dan sebanyak $(50 \%)$ bekerja sebagai pegawai swasta / Lembaga Swadaya Masyarakat (LSM), seperti ditunjukan pada tabel 2.

Analisis Bivariat dilakukan untuk membuktikan hipotesis yang telah dirumuskan dalam menguji variabel penelitian yang didahului dengan uji normalitas data menggunakan Rumus Shapiro-Wilk, sebagai berikut.

Pengaruh edukasi oral hygiene terhadap pengetahuan perawat.

Pengaruh Edukasi Oral hygiene terhadap pengetahuan perawat sebelum dan sesudah edukasi oral hygiene seperti terlihat pada tabel 3 . Tampak bahwa nilai $\mathrm{p}=0.001<0,05$, maka dapat disimpulkan bahwa secara statistik terdapat perbedaan yang bermakna antara pengetahuan perawat pre dan post edukasi oral hygiene.

\section{Pengaruh edukasi oral hygiene terhadap ketrampilan perawat.}

Pengaruh Edukasi Oral hygiene terhadap ketrampilan perawat sebelum dan sesudah edukasi oral hygiene seperti terlihat pada tabel 4 . Terlihat bahwa pemberian edukasi oral hygiene berpengaruh pada peningkatan ketrampilan perawatan dengan nilai $p=0.001<0,05$ pada tabel 4 di atas.

\section{Pengaruh oral hygiene terhadap Status Kesehatan Mulut Berdasarkan Skala BOAS.}

Pengaruh penerapan Oral hygiene Terhadap Skor BOAS sebelum dan sesudah Intervensi dapat diamati pada tabel 5 .

Hasil uji statistik mendapatkan nilai $\mathrm{p}=0.001<0.05$, sehingga dapat dinyatakan ada perbedaan bermakna pada skor BOAS sebelum dan sesudah intervensi oral hygiene. Nilai selisih yang dianggap bermakna adalah 1, maka secara klinis terdapat perbedaan bermakna sebelum dan sesudah intervensi.

\section{Pengaruh penerapan oral hygiene terhadap jumlah Candida albicans oral.}

Pengaruh pre dan post penerapan oral hygiene terhadap jumlah Candida albicans oral tampak pada tabel 6.

Uji statistik pada tabel 6 menunjukkan perolehan nilai signifikansi $\mathrm{p}=0.001<0.05$, Maka secara statistik terdapat pebedaan yang signifikan antara jumlah $\mathrm{C}$. 
albicans sebelum dan sesudah intervensi oral hygiene.

\section{PEMBAHASAN}

Pasien dengan HIV/AIDS yang dirawat di Rumah Sakit pada umumnya mengalami kandidiasis oral yang memerlukan bantuan untuk perawatan mulut. Kandidiasis oral adalah infeksi jamur oportunistik umum rongga mulut dengan prevalensi di seluruh dunia dan tingkat kejadian meningkat dalam beberapa dekade terakhir, terutama di antara populasi orang dengan HIV yang immunocompromised dan dirawat di rumah sakit (Freires et al., 2014). Lesi oral selalu hadir bersama infeksi oportunistik pada orang yang menderita HIV. Kandidiasis adalah salah satu lesi mulut yang paling umum (Meless, Boubacar, \& Faye, 2015). Hasil penelitian menunjukkan bahwa kebersihan mulut yang buruk secara signifikan terkait dengan peningkatan kolonisasi Candida oral, terutama C. albicans (Abduljabbar, Hussain, Adnan, Vohra, \& Javed, 2017). Pendapat dari beberapa penulis bahwa kebersihan mulut yang memuaskan dapat mencegah dan mengobati mukositis oral pada pasien onkologis. (Patussi, Sassi, Munhoz, Stramandinoli, \& Schussel, 2014).

Perawat kurang menyadari pentingnya penerapan oral hygiene dalam praktik sehari-hari termasuk pada pasien dengan HIV/AIDS yang mengalami kandidiasis. Temuan dari sebuah studi menunjukkan bahwa pendidikan perawatan mulut yang substansial tidak dimiliki oleh perawat, baik pada pendidikan awal maupun dalam proses kualifikasi sebagai perawat. Pengetahuan tentang kesehatan mulut dasar yang dimiliki oleh reponden tidak memadai demikian juga pengetahuan tentang peralatan kesehatan mulut dan efek samping dari penggunaan obat-obat perawatan mulut (Groenkjaer, 2015).

Kesibukan, keterbatasan staf perawat, faktor prosedural dan keterbatasan sumber daya serta kurangnya pemahaman tentang pentingnya pemeliharaan kebersihan mulut, menjadi hambatan dalam penerapan bersihan mulut pada pasien dengan HIV/AIDS yang mengalami kandidiasis, seperti yang diungkapkan dalam sebuah studi bahwa Perawat mengalami hambatan ketika mencoba menerapkan oral hygiene sehari-hari secara rutin. Hambatan tersebut berupa pendidikan dan pelatihan staf yang buruk khususnya dalam pelaksanaan oral hygiene pada kondisi fisik yang sulit, tidak adanya prosedur kebersihan mulut yang formal, peralatan dan prioritas penyelesaian pekerjaan yang bersaing (Gibney et al., 2015).

Pedoman untuk perawatan kesehatan mulut pada pasien dengan penyakit sistemik tersedia di Negara maju, namun sebaliknya pada Negara berkembang tidak ada perhatian yang memadai terhadap kebutuhan perawatan kesehatan mulut pada pasien dengan penyakit sistemik, sehingga semakin memperburuk prognosis penyakitnya. (Oyetola, Owotade, Agbelusi, Fatusi, \& Sanusi, 2015).

Pelaksanaan prosedural oral hygiene juga menjadi tantangan bagi perawat karena dalam penerapannya sering meliputi menyikat gigi saja, sementara prosedur lainnya menjadi terabaikan, seperti data dari sebuah studi tentang manfaat biaya dan layanan HIV nasional menemukan bahwa, sejak mengetahui status HIVpositif mereka, hanya $26 \%$ ODHA yang melaporkan flushing setiap hari, $34 \%$ melaporkan lebih sering menyikat dan flushing, $23 \%$ melaporkan mengunjungi dokter gigi dengan frekuensi lebih sedikit dan $11 \%$ melaporkan tidak pernah melakukan pemeriksaan diri (Rajabiun et al., 2012).

Skala BOAS sebagai indikator penilaian status kesehatan mulut yang merupakan variabel dalam penelitian ini yang terdiri dari lima kategori, masing-masing kategori 
diberikan skor 1-4. Total skor dari tiap kategori menunjukkan total skor BOAS yang menggambarkan status kesehatan mulut pasien secara keseluruhan. Semakin tinggi total skor BOAS, menunjukkan tingkat kondisi oral yang semakin parah. Pengukuran yang andal dan valid untuk penilaian lisan sangat penting untuk mengukur kemajuan dan memandu intervensi. Dalam penelitian ini, kami menggunakan BOAS (Ames et al., 2011).

Pada penelitian ini, secara statistik terdapat perbedaan skor BOAS sebelum dan sesudah intervensi. Penurunan nilai median tersebut terjadi karena penerapan oral hygiene yang diberikan oleh perawat kepasien sehingga terjadi kebersihan mulut yang optimal dan meningkatkan rasa nyaman, seperti yang dikatakan pasien; bahwa mereka merasa fressh, setelah oral hygiene. Dalam sebuah studi yang juga menerapkan penggunaan skor BOAS didapatkan bahwa pasien di kelompok intervensi menunjukkan peningkatan keseluruhan dalam skor BOAS antara hari pertama dan lima (Drapal, 2015).

Dalam rongga mulut terdapat berbagai mikroorganisme yang diketegorikan sebagai flora oral normal, termasuk C. albicans. Keberadaan jamur Candida dalam rongga mulut dianggap sebagai komensalisme normal dengan presentase $25 \%$ sampai $50 \%$ dari keseluruhan flora dalam mulut. Namun kondisi ketidakseimbangan antara jamur dan inang, flora komensal ini bisa menyebabkan kondisi pathogen dalam rongga oral seperti kandidiasis (Pinelli, Montandon, Corbi, Moraes, \& Fais, 2013). Kondisi individu terkait dengan perubahan normal menjadi kandidiasis adalah penurunan daya tahan tubuh, penggunaan antibiotik dalam jumlah banyak (multi obat) dan waktu yang lama dan pemeliharaan kebersihan mulut yang tidak adekuat. Sesuai dengan salahsatu studi yang menjelaskan bahwa mereka yang mengalami kondisi penurunan kekebalan tubuh seperti penderita HIV/AIDS, sangat beresiko terhadap kandidiasis (Seleem, Benso, Noguti, Pardi, \& Murata, 2016). Adanya penurunan daya tahan tubuh pada kondisi HIV/AIDS, maka sangat berpeluang bagi $C$. albicans menimbulkan infeksi Kandidiasis seperti dikatakan dalam sebuah studi bahwa ketika kekebalan tubuh terganggu, maka bisa terjadi infeksi kandidiasis opurtunistik (Yang et al., 2016).

Kehadiran kandidiasis ini sering dapat menyebabkan sensasi terbakar, mukositis parah atau disfagia, gangguan rasa dan mengakibatkan gangguan nutrisi yang buruk (Sato et al., 2017). Kegagalan untuk mengobati infeksi kandidiasis tepat waktu dapat menyebabkan malnutrisi dan gangguan metabolisme, sehingga mempengaruhi kualitas hidup pasien; selain itu, kandidiasis oral dapat meningkatkan perkembangan kanker epitel mukosa oral (Yang et al., 2016). Defisit nutrisi pada gilirannya memperparah kerusakan sistem kekebalan tubuh. Dengan demikian membutuhkan penanganan terhadap peningkatan kolonisasi $C$. albicans tersebut.

Berbagai penanganan untuk menekan jumlah kolonisasi $C$. albicans telah dilakukan, seperti penggunaan salin natrium bikarbonat 3\% untuk kebersihan mulut setelah operasi free flap yang mengalami kandidiasis (Yang et al., 2016). Studi untuk menilai manfaat dari Ricinus Communis pada lansia dibandingkan dengan gel oral Miconazole dan Nistatin untuk aktivitas anti jamur (Pinelli et al., 2013). Penerapan lima agen pembersih mulut untuk menurunkan viabilitas biofilm setelah menyikat gigi dengan air, pasta gigi, dan Polident fresh cleanse (Delise et al., 2012).

Efektifitas dari empat agen pembersih mulut, menemukan bahwa natrium hipoklorit dan klorheksidin 
efektif dalam menurunkan viabilitas mikroba serta dapat diaplikasikan bersama sikat gigi mekanik dalam mencegah kolonisasi mikroba menggunakan natrium hipoklorit dibandingkan dengan air dan natrium bikarbonat telah terjadi penurunan $C$. albicans (Valentini-mioso, Maske, Cenci, Boscato, \& Pereira-cenci, 2013). Perawatan mulut menggunakan gel pelembab oral eksperimental dengan anti-CA IgY setiap setelah menyikat gigi telah menunjukkan pengurangan yang signifikan dari jumlah koloni $C$. albicans (Takeuchi, Motohashi, Kimori, Nakagawa, \& Tsurumoto, 2016).

Temuan dari sebuah studi mengungkapkan protokol pembersihan mulut standar dengan menyikat palatal, terbukti efektif dan ekonomis untuk pengobatan jangka panjang atau pencegahan Stomatitis eritematosa, terjadi penurunan pengangkutan Candida oral yang lebih rendah (Souza et al., 2017). Rekolonisasi yang terjadi secara alami setiap saat, menekankan mengapa menyikat dengan sikat gigi dan pasta gigi yang dikombinasikan dengan rutinitas kebersihan harian adalah yang paling penting untuk pemeliharaan gigi palsu lengkap yang bersih (Valentini-mioso et al., 2013). Biasanya resep antijamur diberikan bersamaan dengan instruksi kebersihan mulut (Souza et al., 2017).

Berdasarkan hasil pemeriksaan laboratorium dalam penelitian ini, terdapat perbedaan antara jumlah Candida pre intervensi dan post intervensi, dapat disimpulkan bahwa akibat dari pemeliharaan kebersihan mulut yang optimal sehingga dapat menekan kolonisasi C. albicans, hal ini sejalan dengan studi yang dilakukan, karena kontribusi kebersihan mulut yang buruk dalam prevalensi Candida dan pengangkutan dalam subjek penelitian ini tidak dapat diabaikan (Abduljabbar et al., 2017).
Beberapa penelitian terkait, antara lain studi yang melihat kesehatan mulut di Libya, meninjau secara komprehensif perawatan kesehatan mulut dan sumber daya manusia dengan status pendidikan gigi, mengungkapkan bahwa strategi mendidik profesional medis dan gigi perlu dikembangkan pada aspek perawatan kesehatan mulut dan juga adanya peningkatan yang tajam dari masalah kesehatan mulut pada kasus HIV (Peeran et al., 2014) dan studi lain yang memperoleh hasil dari 2.469 sampel orang dewasa yang telah positif HIV selama satu dekade dan sebagian besar terlibat dalam perawatan HIV, namun mereka yang tidak pernah bertemu dokter gigi selama lebih dari dua tahun adalah $52,4 \%$, sebagian 48,2\% mengatakan belum terpenuhinya kebutuhan perawatan kesehatan mulut sejak tes positif HIV (Fox et al., 2012). Suatu studi di Malasya juga menemukan pengetahuan responden, yakni 37\% memiliki pengetahuan, sedangkan $63 \%$ tidak berpengetahuan tentang manifestasi oral pada kondisi HIV/AIDS (Khan, Moorthy, Omar, \& Hasan, 2012). Ketiga studi terakhir, memberikan gambaran adanya manifesitasi oral pasien HIV/AIDS dan memperlihatkan kebutuhun perawatan mulut, baik dari segi sumber daya meliputi pengetahuan, sikap dan praktik dari tenaga kesehatan maupun penderita serta pembiayaannya, sedangkan pada penelitian ini memberikan edukasi pada perawat dan penerapan perawatan kesehatan mulut pada pasien yang dirawat dengan kasus HIV/AIDS, sehingga penelitian ini memiliki keterbaruan dari penelitian sebelumnya.

\section{KETERBATASAN}

Keterbatasan dari studi ini yaitu waktu penelitian yang tidak cukup mendapatkan sampel dengan jumlah besar, karena pasien HIV/AIDS yang datang pada pelayanan rawat inap 
jumlahnya terbatas dan oleh karena itu tidak adanya kelompok pembanding dalam peneltian ini; menyebabkan kesimpulan yang diambil hanya sepihak saja.

\section{KESIMPULAN}

Pelaksanaan edukasi oral
hygiene dapat meningkatkan
pengetahuan dan ketrampilan
perawat dalam penatalaksanaan oral
hygiene pada pasien dengan
HIV/AIDS. Adanya peningkatan
pengetahuan dan ketrampilan dan
penerapan oral hygiene yang
sistematis dan berkesinambungan
dapat mempengaruhi skor BOAS dan
jumlah mikroorganisme patogen
termasuk C. albicans sehingga dapat
mengurangi kondisi penyakit dan
mencegah tingkat keparahan.

\section{DAFTAR PUSTAKA}

Abduljabbar, T., Hussain, M., Adnan, T., Vohra, F., \& Javed, F. (2017). Comparison of oral Candida species prevalence and carriage among gutkachewers and betel-quid chewers, 350354. Retrieved from https://jpma.org.pk/articledetails $/ 8108$ ?article_id $=8108$

Ames N.J, Sulima P, Yates J,M, McCullagh L,Gollins S.L, Soeken K, Wallen G.R. 2011. Effects of Systematic Oral Care in Critically Ill Patients: A Multicenter Study. American Journal Critical Care : 20(5): e103-e114.

Delise, P., Polyzois, G., Machado, A. L., Giampaolo, E. T., Sanitá, P. V., \& Vergani, C. E. (2012). Effectiveness of Mechanical Brushing with Different Denture Cleansing Agents in Reducing In Vitro Candida albicans Biofilm Viability, 23, 547-554.

Drapal, C. S. (2015). Oral Care Practice Guidelines for the Care- Dependent Hospitalized Adult Outside of the Intensive Care Unit Setting.

Doengoes, M.E, Moorhouse, M. F., \& Murr, A. C. (2015). Nursing Care Plans (9th ed., Vol. 1542). Philadelphia.

Fernanda, C., Vidal, D. L., Karla, A., Vidal, D. L., Gildo, J., Monteiro, D. M., ... Montarroyos, U. (2017). Impact of oral hygiene involving toothbrushing versus chlorhexidine in the prevention of ventilator-associated pneumonia: a randomized study. BMC Infectious Diseases, https://doi.org/10.1186/s12879-0172188-0

Fjeld KG, Eide H, Mowe M, Hove LH, Willumsen $T$. Dental hygiene registration: development, and reliability and validity testing of an assessment scale designed for nurses in institutions. J Clin Nurs. 2017;26(13-14):1845-53.

Fox, J. E., Tobias, C. R., Bachman, S. S., Reznik, D. A., Rajabun, S., \& Verdecias, N. (2012). Increasing Access to Oral Health Care for People Living with HIV / AIDS in the U.S .: Baseline Evaluation Results of the Innovations in Oral Health Care Initiative, 127, 5-16.

Freires, I. de A., Murata, R. M., Furletti, V. F., Sartoratto, A., Alencar, S. M. de, Figueira, G. M., ... Rosalen, P. L. (2014). Coriandrum sativum L . (Coriander) Essential Oil: Antifungal Activity and Mode of Action on Candida spp., and Molecular Targets Affected in Human Whole-Genome Expression, 9(6). https://doi.org/10.1371/journal.pone.0 099086.t001

Gibney, J., Wright, C., Sharma, A., \& Naganathan, V. (2015). Nurse's Knowledge, Attitudes, and Current Practice of Daily Oral Hygiene Care to Patients on Acute Aged Care Wards in Two Australian Hospitals, 5, 285-293. https://doi.org/10.1111/scd.12131

Groenkjaer, L. L. (2015). Oral Care in Hepatology Nursing, 22-30. https://doi.org/ 10.1097/SGA.0000000 000000086

Khan, S. A., Moorthy, J., Omar, H., \& Hasan, S. S. (2012). People living with HIV / AIDS ( PLWHA ) and HIV / AIDS associated oral lesions; a study in Malaysia. BMC Public Health, 12(1), 1. https://doi.org/10.1186/1471-245812-850

Krishnan, P. A. (2012). Fungal Infections of the Oral Mucosa. Kesehatan, 23. https:/ / doi.org/ 10.4103/09709290.107384

Kuteyi, T., \& Okwundu, C. (2012). Topical treatments for HIV-related oral ulcers, (1).

https://doi.org/10.1002/14651858.CD 007975.pub2.www.cochranelibrary.com

Malik, N. A. (2017). Oral Hygiene Practices and Knowledge Among Stroke-Care Nurses: A Multi-Center Cross- Sectional Study. https://doi.org/10.1111/jocn.14241

Meless, D., Boubacar, B., \& Faye, M. (2015). Oral lesions among HIV-infected children on antiretroviral treatment in West Africa, 19(3), 246-255. https://doi.org/10.1111/tmi.12253.Ora 1

Mwangosi, I. E. A. T., \& Majenge, J. M. (2011). Prevalence and awareness of oral manifestations among people living with 
HIV / AIDS attending counselling and treatment centres in Iringa Municipality; Tanzania, 13(3), 1-7.

Nursalam, Ninuk, D. K., Misutarno, \& Kurniasari, F. S. (2018). Asuhan Keperawatan Pada Pasien Terinfeski HIV/AIDS. (P. P. Lestari \& T. U. Utami, Eds.) (Two). Jakarta: Salemba Medika.

Oyetola, E. O., Owotade, F. J., Agbelusi, G. A., Fatusi, O. A., \& Sanusi, A. A. (2015). Oral findings in chronic kidney disease: implications for management in developing countries, 1-8. https://doi.org/10.1186/s12903-0150004-Z

Patussi, C., Sassi, L. M., Munhoz, E. C., Stramandinoli, R. T., \& Schussel, J. L. (2014). Clinical assessment of oral mucositis and candidiasis compare to chemotherapic nadir in transplanted patients, 28(1), 1-7. https: / /doi.org/10.1590/18073107BOR-2014.vol28.0050

Peeran, S. W., Altaher, O. B., Peeran, S. A., Alsaid, F. M., Mugrabi, M. H., \& Ahmed, A. M. (2014). Oral health in Libya: addressing the future challenges, 1, 1-7.

Pinelli, L. A. P., Montandon, A. A. B., Corbi, S. C. T., Moraes, T. A., \& Fais, L. M. G. (2013). Ricinus Communis Treatment of Denture Stomatitis in Institutionalised Elderly, https://doi.org/10.1111/joor.12039

Potter, P. A., Perry, A. G., Stockert, P. A., \& Hall, A. M. (2013). FUNDAMENTALS OF NURSING (EIGHTH EDI). St. Louis, Missouri: Elsevier Inc.

Rajabiun, S., Fox, J. E., McCluskey, A., E., G., Verdecias, N., Jeanty, Y., ... Mofidi, M. (2012). Patient Perspectives on Improving Oral Health-Care Practices Among People Living with HIV / AIDS, 127, 73-81.

Salamone, K., Yacoub, E., Mahoney, A., \& Edward, K. (2013). Oral Care of Hospitalised Older Patients in the Acute Medical Setting, 2013, 4-7.
Sato, T., Kishi, M., Suda, M., Sakata, K., Shimoda, H., Miura, H., \& Ogawa, A. (2017). Prevalence of Candida albicans and non- albicans on the tongue dorsa of elderly people living in a post-disaster area: a cross-sectional survey, 1-10. https://doi.org/10.1186/s12903-0170342-0

Seleem, D., Benso, B., Noguti, J., Pardi, V., \& Murata, R. M. (2016). In Vitro and In Vivo Antifungal Activity of Lichochalcone-A against Candida albicans Biofilms, 1-17. https://doi.org/10.1371/journal.pone.0 157188

Souza, R. F. De, Khiyani, M. F., Chaves, C. A. L., Feine, J., Barbeau, J., Fuentes, R., ... Emami, E. (2017). Improving practice guidelines for the treatment of denturerelated erythematous stomatitis: a study protocol for a randomized controlled trial, $1-8$ https://doi.org/10.1186/s13063-0171947-y

Takeuchi, S., Motohashi, J., Kimori, H., Nakagawa, Y., \& Tsurumoto, A. (2016). Effects of oral moisturising gel containing egg yolk antibodies against Candida albicans in older people, 128134.

https://doi.org/10.1111/ger.12139

Valentini-mioso, F., Maske, T. T., Cenci, M. S., Boscato, N., \& Pereira-cenci, T. (2013). Chemical hygiene protocols for complete dentures: A crossover randomized clinical trial. The Journal of Prosthetic Dentistry, 1-7. https://doi.org/10.1016/j.prosdent.201 7.12 .022

Yang, Y., Zhang, F., Lyu, X., Yan, Z., Hua, H., $\&$ Peng, X. (2016). Prevention Of Oral Candidiasis After Free Flap Surgery: Role of 3\% Sodium Bicarbonate Saline Saline In Oral Care. Journal of Oral and Maxillofacial Surgery. https://doi.org/10.1016/j.joms.2016.08 .037 